\title{
Article \\ The Effects of a Ketogenic Diet on Patients with Dihydrolipoamide Dehydrogenase Deficiency
}

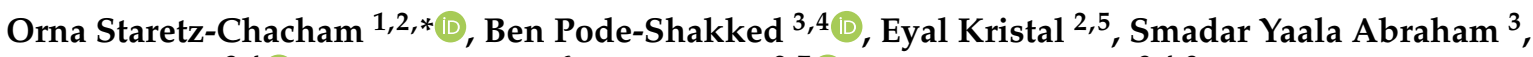 \\ Keren Porper ${ }^{3,4}{ }^{\mathbb{D}}$, Ohad Wormser ${ }^{6}$, Ilan Shelef ${ }^{2,7} \mathbb{D}$ and Yair Anikster ${ }^{3,4,8}$
}

1 Metabolic Clinic, Soroka Medical Center, Beer Sheva 8480101, Israel

2 Faculty of Health Sciences, Ben-Gurion University, Beer Sheva 8410501, Israel; eyalkristal@gmail.com (E.K.); shelef@bgu.ac.il (I.S.)

3 Metabolic Disease Unit, Edmond and Lily Safra Children's Hospital, Sheba Medical Center, Tel-Hashomer, Ramat Gan 5262000, Israel; ben_pode@hotmail.com (B.P.-S.); Smadar.Abraham@sheba.health.gov.il (S.Y.A.); kerenporper83@gmail.com (K.P.); Yair.Anikster@sheba.health.gov.il (Y.A.)

4 Sackler Faculty of Medicine, Tel-Aviv University, Tel-Aviv 6997801, Israel

5 Pediatric Ambulatory Day Unit, Soroka Medical Center, Beer Sheva 8480101, Israel

6 The Morris Kahn Laboratory of Human Genetics, National Institute for Biotechnology in the Negev, Faculty of Health Sciences, Ben Gurion University of the Negev, Beer Sheva 8410501, Israel; wormser@post.bgu.ac.il 7 Department of Radiology, Soroka University Medical Center, Beer Sheva 8480101, Israel

8 The Wohl Institute for Translational Medicine, Sheba Medical Center, Tel-Hashomer, Ramat Gan 5262000, Israel

* Correspondence: staretz@bgu.ac.il; Tel.: +972-5457-13191

Citation: Staretz-Chacham, O.; Pode-Shakked, B.; Kristal, E.;

Abraham, S.Y.; Porper, K.; Wormser, O.; Shelef, I.; Anikster, Y. The Effects of a Ketogenic Diet on Patients with Dihydrolipoamide Dehydrogenase Deficiency. Nutrients 2021, 13, 3523. https://doi.org/10.3390/nu13103523

Academic Editor: Keisuke Hagihara

Received: 24 August 2021

Accepted: 27 September 2021

Published: 7 October 2021

Publisher's Note: MDPI stays neutral with regard to jurisdictional claims in published maps and institutional affiliations.

Copyright: (c) 2021 by the authors. Licensee MDPI, Basel, Switzerland. This article is an open access article distributed under the terms and conditions of the Creative Commons Attribution (CC BY) license (https:/ / creativecommons.org/licenses/by/ $4.0 /)$.
Abstract: Background: Dihydrolipoamide dehydrogenase (DLD lipoamide dehydrogenase, the E3 subunit of the pyruvate dehydrogenase complex (PDHC)) is the third catalytic enzyme of the PDHC, which converts pyruvate to acetyl-CoA catalyzed with the introduction of acetyl-CoA to the tricyclic acid (TCA) cycle. In humans, PDHC plays an important role in maintaining glycose homeostasis in an aerobic, energy-generating process. Inherited DLD-E3 deficiency, caused by the pathogenic variants in DLD, leads to variable presentations and courses of illness, ranging from myopathy, recurrent episodes of liver disease and vomiting, to Leigh disease and early death. Currently, there is no consensus on treatment guidelines, although one suggested solution is a ketogenic diet (KD). Objective: To describe the use and effects of KD in patients with DLD-E3 deficiency, compared to the standard treatment. Results: Sixteen patients were included. Of these, eight were from a historical cohort, and of the other eight, four were on a partial KD. All patients were homozygous for the $\mathrm{D} 479 \mathrm{~V}$ (or D444V, which corresponds to the mutated mature protein without the mitochondrial targeting sequence) pathogenic variant in DLD. The treatment with partial KD was found to improve patient survival. However, compared to a historical cohort, the patients' quality of life (QOL) was not significantly improved. Conclusions: The use of KD offers an advantage regarding survival; however, there is no significant improvement in QOL.

Keywords: dihydrolipoamide dehydrogenase (DLD); pyruvate dehydrogenase complex (PDHC); ketogenic diet

\section{Introduction}

Dihydrolipoamide Dehydrogenase (DLD), also known as the E3 subunit of the pyruvate dehydrogenase complex, EC 1.6.4.3, is the third catalytic enzyme of the pyruvate dehydrogenase complex (PDHC), which is a multifunctional, mitochondrial matrix enzyme. DLD-E3 is a flavoprotein shared by a number of mitochondrial enzymatic complexes: AKGDHc ( $\alpha$-ketoglutarate dehydrogenase complex), BCKDHc (branched chain a-ketoacid dehydrogenase) and pyruvate dehydrogenase complex (PDHc) [1,2]. The main role of $\mathrm{PDHC}$ is to convert pyruvate to acetyl-CoA catalyzed by the oxidative decarboxylation of pyruvate and the formation of acetyl-CoA, $\mathrm{CO} 2$ and $\mathrm{NADH}$ with the introduction 
of acetyl-CoA to the tricarboxylic acid (TCA) cycle. In humans, PDHC acts as the gatekeeper, maintaining glucose homeostasis during the eating and fasting states as part of the metabolism of pyruvate [3]. This is an aerobic, energy-generating pathway [1].

Pathogenic variants in the DLD gene are shown to cause DLD-E3 deficiency. This disorder manifests with a wide spectrum of presentations and courses of illness, ranging from severe neonatal disorders characterized by profound intermittent metabolic acidosis, neurological impairments in the form of Leigh disease and fatal outcomes to myopathy, or recurrent episodes of liver disease and vomiting. Different pathogenic variants are linked with the different presentations, for example: severe neonatal presentation with a cognitive impairment was reported with K72E/P488L [4], I353T and G136del [5], Y35Xins/R495G [6], E375K/p.M361V [7], R482G [8] and the D479V [9] variants reported herein; liver involvement was reported with G229C [10-13] and the myopathic form with I40Lfs*4/G461E [14], I480M [15], etc. (Supplementary Table S1). Three main types of presentation were reported. Firstly, there was the early onset that manifested in early infancy, as early as the first hours of life, with severe lactic acidosis and profound hypotonia. The affected infants most commonly died within the first few years of life during a recurrent metabolic decompensation, and those who lived beyond the first two to three years frequently exhibited severe failures to thrive and residual neurologic deficits (intellectual disability, spasticity, ataxia, and seizures) [16]. The second form of presentation is the late-onset milder form of this disease or the liver involvement characterized by episodic vomiting, metabolic acidosis, hyperammonemia, elevated liver enzymes and hypotonia with no residual deficits between episodes [12]. The acute metabolic decompensation can lead to liver failure and result in death. The third form of presentation is the myopathic form characterized by cramps, muscle weakness, and exertional fatigue with elevated creatine kinase [14].

To date, there is no definitive treatment, nor consensus guidelines or recommended therapy. One of the suggested treatments is a ketogenic diet (KD), a high-fat, lowcarbohydrate diet, which mimics a metabolic state of prolonged starvation, forcing the body to utilize fat as the primary source of energy instead of glucose [17]. KD is utilized as part of the treatment of paediatric patients with refractory seizures and the treatment of choice for certain inborn malfunctions in metabolism $[18,19]$ and should be considered for the treatment of PDHC.

In PDHC deficiency, the glycolytic end product, pyruvate, is not optimally metabolized through the TCA cycle, leading to the increased production of lactate and the impaired production of adenosine triphosphatase (ATP) via the mitochondrial respiratory chain $[19,20]$. As a result of increased fatty acid oxidation in the liver, there is an increase in Acetyl CoA levels. These levels are compressed to generate the ketone bodies (acetate and beta-hydroxybutyrate) and then transferred from the liver to the cells through the bloodstream, serving as an alternative fuel, instead of glucose for the brain [21]. Ketosis is considered to improve lactate levels in PDHC [19,22]. In this case, the ketogenic diet would be expected to lower the lactatemia with an improved survival and quality of life in patients with DLD-E3.

The KD is a restrictive diet which follows strict guidelines. There are four different versions of the KD: the traditional classic ketogenic diet based on a strict ketogenic ratio, calculated by mass (grams), between the fat and protein, and fat and carbohydrate (3:1, 4:1, respectively). Higher ratios result in greater degrees of ketosis and a better efficacy. In a 4:1 ratio, there are $4 \mathrm{~g}$ of fat for every $1 \mathrm{~g}$ of protein and carbohydrate combined. Protein is provided to meet the dietary reference intake, which is approximately $1 \mathrm{~g}$ per kilogram of body weight and carbohydrates complete the remaining allowance of the ratio (90\% of calories coming from fat, $8 \%$ from protein and $2 \%$ from carbohydrate) [23]. KetoCal (Nutricia, Gaithersburg, MD, USA) is a 4:1 ratio, (fat: carbohydrates and protein in grams) and a nutritionally complete, formula-based powder that can be used as a meal substitute for infants and children [23]. The initiation of the diet usually requires hospitalization and weighing individual food items. For a less restrictive KD with a lower ratio, the KetoCal can be combined with a standard infant formula $[23,24]$. 
The medium-chain triglyceride (MCT) diet based on MCT oil secreted from coconut oil, is thought to stimulate the hepatic production of ketone bodies [25]. The MCT diet contains $60 \%$ calories coming from MCT oil as the main source, $11 \%$ from polyunsaturated sources, $10 \%$ from protein and $19 \%$ from carbohydrates. This results in a ratio of fat to non-fat of approximately 1:1, allowing more carbohydrates in the diet compared to the classic KD [23,25].

The Modified Atkins Diet and a diet with a Low Glycemic Index are considered less restrictive diets and usually administered for older children. Both versions result in an approximate ratio of 1:1(fat to nonfat), with $60-65 \%$ of calories coming from fat, $30 \%$ from protein, and $5-10 \%$ from carbohydrates [26,27]. The initiation of this diet does not require hospitalization, nor weighing individual food items.

Despite the efficacy of KD in patients with epilepsy and certain metabolic diseases, such as GLUT1 deficiency [28] and PDHC deficiency [22,29-31], many patients find it very difficult to persist with a prolonged restrictive diet like the ketogenic diet, especially when the treatment is for life [32].

So far, based on the previous experience of KD for PDHC as reported in the literature, seven patients diagnosed with DLD-E3 deficiency were treated with KD, five of them had no clinical or biochemical benefits, of these the conditions of two patients worsened and the other two improved clinically [7,33-35].

Based on the above reports and the severity of the disease in the current mutation, we hypothesized that a less restrictive partial KD would improve the patients' quality of life while still remaining effective and would ameliorate the survival of these patients.

In this paper we report a novel approach of a less restrictive partial KD for patients diagnosed with DLD-E3 deficiency in a single medical center, all homozygous to the same mutation, which harbors a fatal Leigh disease phenotype.

\section{Materials and Methods}

Every patient born at the Soroka Medical Center between 2016 and 2020 and diagnosed with DLD-E3 due to homozygosity of the D479V pathogenic variant in the DLD gene (NM_000108.5) was offered a KD as detailed below.

We compared DLD patients born between 2016 and 2020 to a historical cohort of patients born between 2000 and 2016, focusing on data regarding the survival and quality of life, by measurements of development as well as imaging studies.

The study was conducted according to the guidelines of the Declaration of Helsinki, and approved by the Institutional Review Board (IRB) of the Soroka Medical Center (approval number SOR-0159-19). The need for individual written informed consent was waived as the study was based on questionnaires filled out by the attending physicians, and the paper does not contain identifiable personal details nor patient photos.

\subsection{Dietary Intervention}

\subsubsection{Partial Ketogenic Diet}

The patients on a partial KD received KetoCal (Nutricia, Gaithersburg, MD, USA), a high-fat content formula (based on 4:1 ketogenic ratio) combined with a based milk standard infant formula, as part of their diet, with $60-70 \%$ of the total energy coming from fat. Protein was provided to meet infant dietary reference intake and above $(2.5-3.5 \mathrm{~g} / \mathrm{kg})$ according to their nutritional needs. (Dietary details presented in Table 1).

Table 1. Details of ketogenic diet for each patient.

\begin{tabular}{cccccccccc}
\hline Patient No. & Age * & $\begin{array}{c}\text { Weight } \\
\mathbf{( K g )}\end{array}$ & $\begin{array}{c}\text { Height } \\
\mathbf{( c m )}\end{array}$ & Kcal & Kcal/Kg & Protein & Protein/Kg & \%Fat & Ketogenic Ratio \\
\hline 12 & 3 y 3 m & 7.900 & 79.8 & 1284 & 162.5 & 27.7 & 3.5 & 67.9 & $1: 1.06$ \\
7 & 4 y 2 m & 12.55 & 99 & 1362 & 108.5 & 41.8 & 3.3 & 61.5 & $1: 1.4$ \\
16 & 3 y & 7.940 & 79 & 923.2 & 116.2 & 20.1 & 2.53 & 63.5 & $1: 1.29$ \\
6 & 5 y & 10.900 & 95 & 1027 & 94.2 & 32.1 & 2.94 & 61.5 & $1: 1.4$ \\
\hline
\end{tabular}

\footnotetext{
* All data is in current status.
} 


\subsubsection{Parenteral Nutrition}

All patients (regardless of KD) received lipofundin (B. Braun Melsungen AG, Melsungen, Germany) or SMOFlipid emulsion (Fresenius Kabi AB, Uppsala, Sweden) of up to $4 \mathrm{~g} / \mathrm{kg} /$ day during a crisis as a supply of energy, and essential fatty acids and omega-3 fatty acids, as part of a parenteral nutrition regimen when oral or enteral nutrition was impossible, insufficient or contra-indicated. At the same time, hepatic enzymes were monitored.

\subsection{Imaging Studies}

Brain magnetic resonance imaging (MRI) was performed as a clinical study in all treated by KD cases. Standard clinical protocols were used including T1, T2, and T1 fluidattenuated inversion recovery and diffusion-weighted imaging. All images were reviewed by a pediatric neuroradiologist.

\subsection{Biochemical Studies}

Biochemical tests, including serum liver transaminases, serum lactate levels and venous blood gases, were periodically obtained as part of the clinical investigations, and performed by the Clinical Laboratory of the Soroka Medical Center.

\section{Results}

During the study period, eight patients were diagnosed as homozygous to D479V in the DLD gene, and four of them were treated with a ketogenic diet, and prescribed with additional sodium bicarbonate as needed. All patients treated with a partial KD underwent the insertion of a percutaneous gastrostomy (PEG), and one had a Nissen funduplication procedure. Patients treated with a partial ketogenic diet were fed orally or by PEG according to their choice. The other four were only treated with sodium bicarbonate, according to their parents' decisions.

The historical cohort included eight patients diagnosed as homozygous to D479V in the DLD gene born between 2000-2016. Of the eight patients in the historical cohort, only two (25\%) survived beyond 3.5 years with a weight of less than $10 \mathrm{~kg}$ (patients 9,10, Table 2), and all were severely encephalopathic and did not reach any developmental milestones (Table 3).

Table 2. Demographic and clinical characteristics of patients with dihydrolipoamide dehydrogenase deficiency. Patients treated with partial ketogenic diet appear in bold.

\begin{tabular}{|c|c|c|c|c|c|c|c|}
\hline Pt. No. & $\begin{array}{l}\text { Gestational } \\
\text { Age }\end{array}$ & Gender & $\begin{array}{c}\text { Current } \\
\text { Age/Death * } \\
\text { (d/m/y) }\end{array}$ & First Presentation & $\begin{array}{c}\text { Age at First } \\
\text { Presentation }\end{array}$ & Treatment & $\begin{array}{c}\text { No. of Hospi- } \\
\text { talizations } \\
\text { (Per Year) }\end{array}$ \\
\hline $1^{\mathrm{h}}$ & $33+2$ weeks & $\mathrm{F}$ & $* 37 \mathrm{~m}$ & Metabolic acidosis & Birth & Started Ketocal at $2 \mathrm{y}$ & $2-5$ \\
\hline $2^{h}$ & Term/SGA & $\mathrm{F}$ & * $29 \mathrm{~m}$ & Metabolic acidosis & Birth & Bicarbonate in crisis & 2 \\
\hline $3^{\mathrm{h}}$ & Term/SGA & M & $* 3 \mathrm{~d}$ & Metabolic acidosis & Birth & Fluids & - \\
\hline $4^{\mathrm{h}}$ & Term & $M$ & $* 4 \mathrm{~d}$ & Metabolic acidosis & $2 d$ & Fluids & - \\
\hline $5^{h}$ & Term & $\mathrm{F}$ & $* 3 \mathrm{~m}$ & Metabolic acidosis & Birth & Fluids & 1 \\
\hline k 6 & Late Preterm & $\mathbf{M}$ & $4.9 \mathrm{y}$ & $\begin{array}{l}\text { Metabolic acidosis } \\
\text { and hypoglycemia }\end{array}$ & $1 \mathrm{~d}$ & $\begin{array}{l}\text { Partial ketogenic diet } \\
\text { and Bicarbonate }\end{array}$ & 2 \\
\hline k 7 & Term & $\mathbf{M}$ & $4.1 \mathrm{y}$ & $\begin{array}{l}\text { Metabolic acidosis } \\
\text { and hypoglycemia }\end{array}$ & $1.5 \mathrm{~d}$ & $\begin{array}{l}\text { Partial ketogenic diet } \\
\text { and Bicarbonate }\end{array}$ & $1-6$ \\
\hline $8^{\mathrm{h}}$ & Term & $\mathrm{M}$ & $* 3 \mathrm{~d}$ & Metabolic acidosis & Birth & - & - \\
\hline $9^{h}$ & Term & $\mathrm{F}$ & $16 y$ & $\begin{array}{l}\text { Metabolic acidosis } \\
\text { and cutis }\end{array}$ & Birth & Canola oil & $1-2$ \\
\hline $10^{\mathrm{h}}$ & Term/SGA & M & $14.2 \mathrm{y}$ & $\begin{array}{l}\text { Metabolic acidosis } \\
\text { and hypertonus }\end{array}$ & Birth & - & $2-5$ \\
\hline 11 & Term & M & $4.3 \mathrm{y}$ & Metabolic acidosis & Birth & Bicarbonate & 1 \\
\hline $\mathrm{k}_{12}$ & Term & F & $3.2 \mathrm{y}$ & Metabolic acidosis & Birth & $\begin{array}{l}\text { Partial ketogenic diet } \\
\text { and Bicarbonate }\end{array}$ & $4-6$ \\
\hline
\end{tabular}


Table 2. Cont.

\begin{tabular}{|c|c|c|c|c|c|c|c|}
\hline Pt. No. & $\begin{array}{l}\text { Gestational } \\
\text { Age }\end{array}$ & Gender & $\begin{array}{c}\text { Current } \\
\text { Age/Death * } \\
\text { (d/m/y) }\end{array}$ & First Presentation & $\begin{array}{c}\text { Age at First } \\
\text { Presentation }\end{array}$ & Treatment & $\begin{array}{l}\text { No. of Hospi- } \\
\text { talizations } \\
\text { (Per Year) }\end{array}$ \\
\hline 13 & Term & M & $3.5 \mathrm{y}$ & Metabolic acidosis & $18 \mathrm{~m}$ & Bicarbonate & 4 \\
\hline 14 & Term/SGA & $\mathrm{F}$ & $1.5 \mathrm{y}$ & Metabolic acidosis & Birth & Bicarbonate & 4 \\
\hline 15 & Term/SGA & $\mathrm{F}$ & $1.5 \mathrm{y}$ & Metabolic acidosis & Birth & Bicarbonate & 4 \\
\hline $\mathrm{k} 16$ & Term & $\mathbf{M}$ & $2.8 \mathrm{y}$ & $\begin{array}{l}\text { Metabolic acidosis } \\
\text { and seizures }\end{array}$ & Birth & $\begin{array}{l}\text { Partial ketogenic diet } \\
\text { and Bicarbonate }\end{array}$ & $2-3$ \\
\hline
\end{tabular}

SGA, small for gestational age. * Age of death. ${ }^{\mathrm{h}}$ Historical cohort. ${ }^{\mathrm{K}}$ Ketogenic Diet.

Table 3. Further clinical characteristics in patients with dihydrolipoamide dehydrogenase deficiency: hypoglycemic events and developmental milestones.

\begin{tabular}{|c|c|c|c|c|c|c|c|}
\hline $\begin{array}{l}\text { Pt. } \\
\text { No. }\end{array}$ & $\begin{array}{c}\text { Current } \\
\text { Age/Death * } \\
\text { (D) }-(\mathrm{d} / \mathrm{m} / \mathrm{y})\end{array}$ & GER & $\begin{array}{c}\text { Liver } \\
\text { Disease }\end{array}$ & Hypoglycemia & Most Advanced Development & Seizure & $\begin{array}{l}\text { DD/ID/ } \\
\text { PMD }\end{array}$ \\
\hline $1^{\mathrm{h}}$ & * $37 \mathrm{~m}$ & No & No & No & Smiled & No & Severe \\
\hline $2^{h}$ & * $29 \mathrm{~m}$ & No & No & Repeated & Rolled both sides, said syllables & No & Severe \\
\hline $3^{h}$ & $* 3 \mathrm{~d}$ & No & No & Yes & NA & No & NA \\
\hline $4^{\mathrm{h}}$ & $* 4 \mathrm{~d}$ & No & No & Yes & NA & No & NA \\
\hline $5^{\mathrm{h}}$ & $* 3 \mathrm{~m}$ & No & No & Yes & Hypertonus, no spontaneous smiles & No & Severe \\
\hline k 6 & $4.9 \mathrm{y}$ & No & $\begin{array}{l}\text { During } \\
\text { crisis }\end{array}$ & Yes & $\begin{array}{l}\text { Sat, rolled, said five words but regressed at } 46 \\
\text { months } \\
\text { and now does not say a word and no eye } \\
\text { contact }\end{array}$ & No & Severe \\
\hline k 7 & $4.1 \mathrm{y}$ & Severe & $\begin{array}{l}\text { During } \\
\text { crisis }\end{array}$ & Yes & $\begin{array}{l}\text { Rolls both sides, says syllables, sat with } \\
\text { support, } \\
\text { said } 7 \text { words but regressed at } 48 \text { months } \\
\text { and now does not say a word and only smiles }\end{array}$ & Yes & Severe \\
\hline $8^{h}$ & $* 3 \mathrm{~d}$ & No & No & No & NA & No & NA \\
\hline $9^{\mathrm{h}}$ & $16 \mathrm{y}$ & No & $\begin{array}{l}\text { Mild } \\
\text { during } \\
\text { crisis }\end{array}$ & No & $\begin{array}{l}\text { Severe spastic PMD, no communication, } \\
\text { mastication movements }\end{array}$ & No & Severe \\
\hline $10^{\mathrm{h}}$ & $14.2 \mathrm{y}$ & No & $\begin{array}{l}\text { During } \\
\text { crisis }\end{array}$ & During crisis & Severe spastic PMD, no communication & No & Severe \\
\hline 11 & $4.3 \mathrm{y}$ & No & No & During crisis & Smiles, says syllables, rolls and sits by himself & No & $\begin{array}{l}\text { Moderate } \\
\text { to severe }\end{array}$ \\
\hline k 12 & $3.2 \mathrm{y}$ & No & No & During crisis & $\begin{array}{c}\text { Smiles; says syllables, rolls both sides, } \\
\text { transfers objects, } \\
\text { holds her bottle, sits with support }\end{array}$ & Yes & $\begin{array}{l}\text { Moderate } \\
\text { to severe }\end{array}$ \\
\hline 13 & $3.5 \mathrm{y}$ & No & No & No & Wandering eyes, no communication & Yes & Severe \\
\hline 14 & $1.5 \mathrm{y}$ & No & No & During crisis & Smiles, rolls both sides, says syllables & No & $\begin{array}{l}\text { Moderate } \\
\text { to severe }\end{array}$ \\
\hline 15 & $1.5 \mathrm{y}$ & No & No & During crisis & $\begin{array}{l}\text { Smiles, rolls both sides, says syllables, } \\
\text { sits with support }\end{array}$ & No & $\begin{array}{l}\text { Moderate } \\
\text { to severe }\end{array}$ \\
\hline k 16 & $2.8 \mathrm{y}$ & No & No & No & Smiles, rolls both sides, says syllables & Yes & Severe \\
\hline
\end{tabular}

DD, developmental delay; GER, gastroesophageal reflux; ID, intellectual disability; NA, not available; PMD, psychomotor delay; * Age of death, ${ }^{\mathrm{h}}$ Historical cohort, ${ }^{\mathrm{k}}$ Ketogenic Diet.

Only three patients (19\%) of the whole cohort did not have any episodes of hypoglycemia, and the others had recurrent episodes during the metabolic crises. Only four patients $(25 \%)$ had liver disease with elevated transaminases during metabolic crises (Table 3).

Four patients had urine organic profiles that all revealed elevated 2-OH-Butyrate and 3-OH-Butyrate $>$ Acetoacetate (Table 4). 
Table 4. Biochemical studies in patients with dihydrolipoamide dehydrogenase deficiency.

\begin{tabular}{|c|c|c|c|c|}
\hline Pt. No. & Urine Organic Acids & $\begin{array}{l}\text { Highest Lactate } \\
\text { (Norm: } 0.5-2.2 \\
\text { mmol/L) }\end{array}$ & $\begin{array}{c}\text { Pyruvate } \\
\text { (Norm: } 0.03-0.08 \\
\text { mmol/L) }\end{array}$ & $\begin{array}{c}\text { Lactate/Pyruvate } \\
\text { Ratio }\end{array}$ \\
\hline $1^{\mathrm{h}}$ & NA & 19 & NA & NA \\
\hline $2^{h}$ & $\begin{array}{c}\text { Elevated lactate, } 2-\mathrm{OH} \text {-Butyrate } \\
\text { Elevated 3-OH-Butyrate > Acetoacetate }\end{array}$ & 7.6 & 1.98 & 3.88 \\
\hline $3^{h}$ & NA & 17 & 2 & 8.5 \\
\hline $4^{\mathrm{h}}$ & NA & 18 & 1 & 18 \\
\hline $5^{\mathrm{h}}$ & NA & 5.8 & 0.3 & 19.3 \\
\hline k 6 & $\begin{array}{c}\text { Elevated lactate, } 2-\mathrm{OH} \text {-Butyrate } \\
\text { Elevated 3-OH-Butyrate }>\text { Acetoacetate }\end{array}$ & 14.3 & 0.54 & 26.5 \\
\hline $\mathrm{k} 7$ & $\begin{array}{l}\text { Massively elevated lactate } \\
\text { and moderately dicarboxylic and } \\
\text { 3-hydroxybutyric acids }\end{array}$ & 29.9 & 0.28 & $9.2 *$ \\
\hline $8^{h}$ & NA & NA & NA & NA \\
\hline $9^{h}$ & NA & 10.4 & 0.38 & 27.4 \\
\hline $10^{\mathrm{h}}$ & NA & 11.5 & 0.73 & 15.7 \\
\hline 11 & NA & 5.7 & 0.07 & 81.1 \\
\hline k 12 & $\begin{array}{c}\text { Elevated lactate, } 2-\mathrm{OH} \text {-Butyrate } \\
\text { Elevated 3-OH-Butyrate }>\text { Acetoacetate }\end{array}$ & 9.5 & 0.1 & 95.5 \\
\hline 13 & $\begin{array}{l}\text { Massively elevated lactate } \\
\text { and ketones and Krebs metabolites }\end{array}$ & 14.8 & 0.17 & 87 \\
\hline 14 & NA & 5.6 & 0.06 & 93.2 \\
\hline 15 & NA & 3.2 & 0.1 & 31.9 \\
\hline $\mathrm{k} 16$ & NA & 8.2 & 0.23 & 35.5 \\
\hline
\end{tabular}

* The lactate:pyruvate ratio was calculated from the same sample. ${ }^{\mathrm{h}}$ Historical cohort, ${ }^{\mathrm{k}}$ Ketogenic Diet.

Six patients underwent brain imaging by magnetic resonance imaging (MRI) (patients $6,7,11,12,13,16$; of these, patients 11 and 13 were on regular diet) which revealed the partial agenesis of corpus callosum with a restriction of the dentate nucleus, moderate ventriculomegaly, the restriction of globus pallidum and of the midbrain (Figure 1), with no difference between those on PD to those on a regular diet (Table 5).
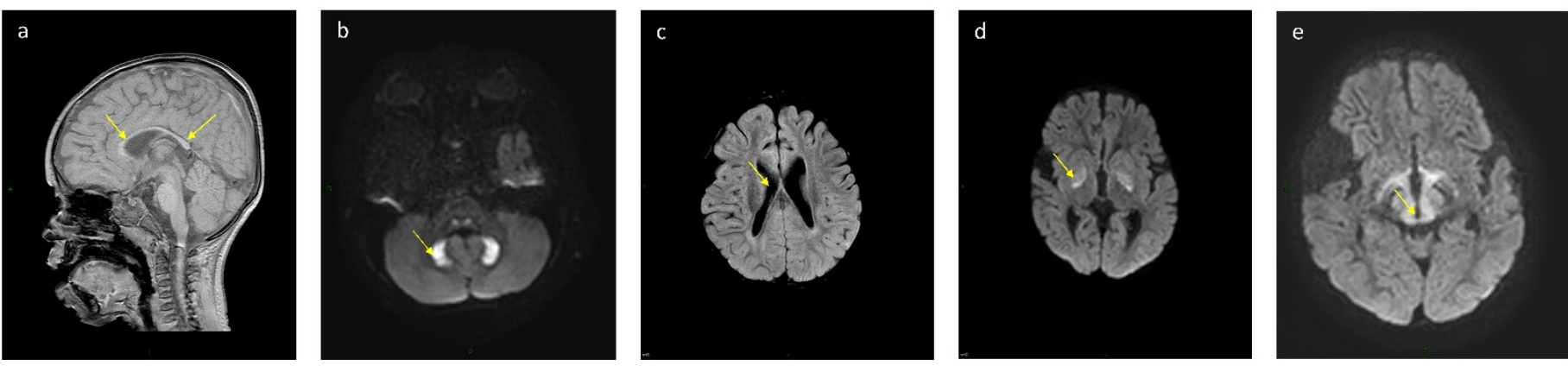

Figure 1. Representative Brain MRIs: (a) partial agenesis of corpus callosum. (b) DWI restriction of dentate nucleus. (c) moderate ventriculomegaly. (d) 2-DWI restriction of globus pallidum. (e) 2-DWI restriction of midbrain. 
Table 5. Imaging studies of patients 6,7, 11-13,16.

\begin{tabular}{|c|c|c|c|c|c|}
\hline $\begin{array}{l}\text { Patient } \\
\text { No. }\end{array}$ & Globus Pallidum & Dentate Nucleus & Corpus Callosum & Ventriculomegaly & $\begin{array}{l}\text { Midbrain and } \\
\text { Thalamus }\end{array}$ \\
\hline k 16 & $\begin{array}{l}\text { T2, Flair, DWI high signal, } \\
\text { T1 low signal }\end{array}$ & Normal & Partial agenesis & Mild & Normal \\
\hline 11 & $\begin{array}{l}\text { T2, Flair, DWI high signal, } \\
\text { T1 low signal }\end{array}$ & $\begin{array}{l}\text { T2, Flair, DWI high } \\
\text { signal, T1 low } \\
\text { signal }\end{array}$ & Partial agenesis & No & Normal \\
\hline $\mathrm{k} 12$ & $\begin{array}{l}\text { T2, Flair, DWI high signal, } \\
\text { T1 low signal }\end{array}$ & Normal & Partial agenesis & Mild & Normal \\
\hline 13 & $\begin{array}{l}\text { T2, Flair, DWI high signal, } \\
\text { T1 low signal }\end{array}$ & Normal & Partial agenesis & Moderate & Normal \\
\hline $\mathrm{k} 6$ & $\begin{array}{c}\text { T2, Flair, DWI high signal, } \\
\text { T1 low signal }\end{array}$ & Normal & Partial agenesis & Mild & Normal \\
\hline k 7 & Normal & $\begin{array}{l}\text { T2, Flair, DWI high } \\
\text { signal, T1 low } \\
\text { signal }\end{array}$ & Partial agenesis & Mild & $\begin{array}{l}\text { T2, Flair, DWI high } \\
\text { signal, T1 low } \\
\text { signal }\end{array}$ \\
\hline
\end{tabular}

\section{Discussion}

DLD-E3 is a rare disorder with a variable spectrum of presentation and course of disease. We present a cohort homozygous to the same severe mutation with a devastating disease. Currently, there is neither a definitive treatment, nor consensus management guidelines for patients with DLD-E3 deficiency.

All the patients in our cohort were homozygous to the p.D479V (or p.D444V) [8] mutation in the DLD gene. So far, there is only one previous report of a patient homozygous to this mutation in the literature [9]. Additionally, so far only a few dozen [36] patients with DLD-E3 are reported worldwide (their clinical and molecular characteristics are summarized in Supplementary Table S1), and we add here a cohort of an additional 16 patients.

Shany et al. compared the current mutation to the G229C mutation, which was reported in recurrent episodic liver failure, and found that, although the DLD-E3 residual activity in the muscle homogenate was higher in the current mutation than in G229C, the multi-enzymatic complex activity in the current mutation was undetectable compared to the G229C with a higher residual activity. This most likely resulted from the location of the discussed mutation in the interface domain which led to the impaired stabilization of the PDHC complex, which was more important than the DLD-E3 for the activity, and therefore led to severe neurodegenerative disease [9].

Ambrus et al. found that the selected pathogenic variants of DLD-E3, including the $\mathrm{D} 444 \mathrm{~V}$, produced elevated amounts of reactive oxygen species (ROS) that led to mitochondrial oxidative stress, resulting in brain damage. In addition, certain pathogenic variants will also lose their affinity for the E2 component of the PDHc, whilst a comparison with the PDHC showed only a significant ROS elevation in vitro [37]. The above described process oxidatively damaged the LA-cofactors KGDHc and PDHc, in the case of D444V, in human homozygous fibroblasts [38]. These could partially explain why KD that was built on lipids did not yield an improvement as expected in patients with DLD-E3 mutations.

Most of our patients in the past had a severe fatal course of the disease with early death, within 3 months in four patients of the historical cohort. The patients who were treated with a less restrictive partial KD in our study, also presented similar to these patients at birth, at least one of them presented two hours after birth with seizures due to hypoglycemia and acidosis; however, they did not succumb and survived the perinatal crisis, most likely due to close monitoring and mainly with the addition of fats in the diet and the frequent treatment with sodium bicarbonate. The addition of fats in the forms of lipofundin (B. 
Braun Melsungen AG, Melsungen, Germany) or SMOFlipid emulsion (Fresenius Kabi AB, Uppsala, Sweden) up to $4 \mathrm{~g} / \mathrm{kg}$ /day changed the disease progression during the crisis in these severely affected patients, with a significant improvement following the introduction or increment of the fat amount.

Additionally, in recent years the close monitoring of these patients with an improved supportive therapy also added to the embellished survival rate, although the quality of life did not significantly improve. In this study we found that even if a patient achieves delayed milestones and says a few words, with time they unfortunately deteriorate to chronic encephalopathy, as can be seen in the description of patients (pt.7) (Table 2).

As can be noted in Table 4, the lactate-pyruvate ratio in eight patients was $>20$ which could be observed, either by taking after feeds, by improved control or even as an unreliable measure. No correlation to the diet was noted.

Brain imaging studies demonstrated that, even with the strict management and partial PD, patients 8, 11, and 13 all showed the severe changes consistent with Leigh disease. Additionally, when comparing these exams to brain MRIs of patients 12 and 14, who were on regular diets due to their parents' preferences, no significant differences were seen.

One of the major issues to consider was the safety of treatment and, although the sample is small, none of our patients deteriorated under this regimen, nor developed any adverse events. Our findings were supported by a few studies indicating that the KD was an efficient and safe treatment during childhood. Its adverse effects, although common, were very mild [39-41]. Furthermore, more palatable but related diets, such as the modified Atkins diet (MAD) or the less restrictive KD, like the one evaluated in our study, were associated with fewer adverse effects [42-44]. However, these should be implemented under careful medical supervision.

The strength of our study is a cohort of 16 patients all homozygous to the same mutation of a rare disease, with only about twice as many [36] such patients reported in the literature to date. A limitation of the study is the lack of formal cognitive tests, although, due to the severity of the phenotype, these could not be performed.

As mentioned above, the administration of a less restrictive partial KD prolongs life; however, the quality of life does not seem to significantly improve, and even if there is a partial gaining of milestones, the patients eventually lose their acquired abilities. Thus, it is probable that the prenatal damage is so significant that, even with close monitoring and a specific diet, we cannot currently overcome it.

\section{Conclusions}

Our results show that while the treatment of patients with DLD-E3 deficiency with a partial KD improves survival (Table 2), the quality of life is not improved. Thus, we need to consider whether a stricter diet might have an improved quality of life. Another important consideration should be whether, with such a difficult regimen and no supportive results, this treatment should be offered to families. Additionally, we should consider future therapeutic measures such as vitamin supplementation, for example riboflavin as previously recommended [14], the supplementation of triheptanoin, or a targeted gene therapy.

Supplementary Materials: The following are available online at https:/ /www.mdpi.com/article/ $10.3390 /$ nu13103523/s1, Table S1. Key clinical and molecular characteristics of patients with dihydrolipoamide dehydrogenase (DLD) deficiency. References [45-49] are referred to in Supplementary Materials.

Author Contributions: Conceptualization, O.S.-C. and Y.A.; methodology, O.S.-C., E.K. and S.Y.A.; formal analysis, K.P. and I.S.; data curation, O.S.-C., B.P.-S., E.K., S.Y.A., K.P., I.S., Y.A., O.W.; writingoriginal draft preparation, O.S.-C., E.K., S.Y.A., K.P., I.S.; writing-review and editing, O.S.-C., B.P.-S., Y.A., O.W.; supervision, O.S.-C. All authors have read and agreed to the published version of the manuscript.

Funding: This research received no external funding. 
Institutional Review Board Statement: The study was conducted according to the guidelines of the Declaration of Helsinki and approved by the Institutional Review Board of the Soroka Medical Center, Israel (approval number SOR-0159-19).

Informed Consent Statement: Patient consent was waived as the manuscript does not contain identifiable details or patient photos.

Data Availability Statement: The datasets generated and analyzed during the current study are not publicly available due to patient privacy and confidentiality, but are available from the corresponding author upon reasonable request.

Conflicts of Interest: The authors declare no conflict of interest.

\section{References}

1. Patel Mulchand, S.; Roche, T.E. Molecular Biology and Biochemistry of pyruvate dehydrogenase complexes. FASEB J. 1990, 4 , 3224-3233. [CrossRef]

2. Cameron, J.M.; Levandovskiy, V.; Mackay, N.; Raiman, J.; Renaud, D.L.; Clarke, J.T.; Feigenbaum, A.; Elpeleg, O.; Robinson, B.H. Novel Mutations in Dihydrolipoamide Dehydrogenase Deficiency in Two Cousins with Borderline-Normal PDH Complex Activity. Am. J. Med. Genet. Part A 2006, 140, 1542-1552. [CrossRef] [PubMed]

3. Patel, M.S.; Nemeria, N.S.; Furey, W.; Jordan, F. The pyruvate dehydrogenase complexes: Structure-based function and regulation. J. Biol. Chem. 2014, 289, 16615-16623. [CrossRef]

4. Liu, T.C.; Kim, H.; Arizmendi, C.; Kitano, A.; Patel, M.S. Identification of two missense mutations in a dihydrolipoamide dehydrogenase-deficient patient. Proc. Natl. Acad. Sci. USA 1993, 90, 5186-5190. [CrossRef] [PubMed]

5. Quinonez, S.C.; Leber, S.M.; Martin, D.M.; Thoene, J.G.; Bedoyan, J.K. Leigh syndrome in a girl with a novel DLD mutation causing E3 deficiency. Pediatr. Neurol. 2015, 48, 67-72. [CrossRef] [PubMed]

6. Hong, Y.S.; Kerr, D.S.; Craigen, W.J.; Tan, J.; Pan, Y.; Lusk, M.; Patel, M.S. Identification of two mutations in a compound heterozygous child with dihydrolipoamide dehydrogenase deficiency. Hum. Mol. Genet. 1996, 5, 1925-1930. [CrossRef]

7. Cerna, L.; Wenchich, L.; Hansiková, H.; Kmoch, S.; Pešková, K.; Chrastina, P.; Brynda, J.; Zeman, J. Novel mutations in a boy with dihydrolipoamide dehydrogenase deficiency. Med. Sci. Monit. 2001, 7, 1319-1325. [PubMed]

8. Odièvre, M.; Chretien, D.; Munnich, A.; Robinson, B.H.; Dumoulin, R.; Masmoudi, S.; Kadhom, N.; Rotig, A.; Rustin, P.; Bonnefont, J.-P. A Novel Mutation in the Dihydrolipoamide Dehydrogenase E3 Subunit Gene (DLD) Resulting in an Atypical Form of $\alpha$ -Ketoglutarate Dehydrogenase Deficiency. Hum. Mutat. 2005, 790, 1-10. [CrossRef] [PubMed]

9. Shany, E.; Saada, A.; Landau, D.; Shaag, A.; Hershkovitz, E.; Elpeleg, O.N. Lipoamide Dehydrogenase Deficiency Due to a Novel Mutation in the Interface Domain. Biochem. Biophys. Res. Commun. 1999, 262, 163-166. [CrossRef] [PubMed]

10. Hong, Y.S.; Korman, S.H.; Lee, J.; Ghoshal, P.; Wu, Q.; Barash, V.; Kang, S.; Oh, S.; Kwon, M.; Gutman, A.; et al. Identification of a common mutation (Gly194Cys) in both Arab Moslem and Ashkenazi Jewish patients with dihydrolipoamide dehydrogenase (E3) deficiency: Possible beneficial effect of vitamin therapy. J. Inherit. Metab. Dis. 2003, 26, 816-818. [CrossRef]

11. Sansaricq, C.; Pardo, S.; Balwani, M.; Grace, M.; Raymond, K. Biochemical and molecular diagnosis of lipoamide dehydrogenase deficiency in a North American Ashkenazi Jewish family. J. Inherit. Metab. Dis. 2005, 29, 203-204. [CrossRef] [PubMed]

12. Shaag, A.; Saada, A.; Berger, I.; Mandel, H.; Joseph, A.; Feigenbaum, A.; Elpeleg, O.N. Molecular Basis of Lipoamide Dehydrogenase Deficiency in Ashkenazi Jews. Am. J. Med. Genet. 1999, 82, 177-182. [CrossRef]

13. Aptowitzer, I.; Saada, A.; Faber, J.; Kleid, D.E.O. Liver disease in the Ashkenazi-Jewish lipoamide dehydrogenase deficiency. J. Pediatr. Gastroenterol. Nutr. 1997, 24, 599-601. [CrossRef]

14. Carrozzo, R.; Torraco, A.; Fiermonte, G.; Martinelli, D.; Di Nottia, M.; Rizza, T.; Vozza, A.; Verrigni, D.; Diodato, D.; Parisi, G.; et al. Riboflavin responsive mitochondrial myopathy is a new phenotype of dihydrolipoamide dehydrogenase deficiency: The chaperon-like effect of vitamin B2. Mitochondrion 2014, 18, 49-57. [CrossRef]

15. Quintana, E.; Pineda, M.; Font, A.; Vilaseca, M.A.; Tort, F.; Ribes, A.; Briones, P. Dihydrolipoamide dehydrogenase (DLD) deficiency in a Spanish patient with myopathic presentation due to a new mutation in the interface domain. J. Inherit. Metab. Dis. 2010, 33, S315-S319. [CrossRef]

16. Quinonez, S.C.; Thoene, J.G. Dihydrolipoamide Dehydrogenase Deficiency Summary. GeneReviews 2014, 1-19. [PubMed]

17. Swink, T.D.; Vining, E.P.F.J. The ketogenic diet: 1997. Adv. Pediatr. 1997, 44, 297-329.

18. Neal, E.G.; Chaffe, H.; Schwartz, R.H.; Lawson, M.S.; Edwards, N.; Fitzsimmons, G.; Whitney, A.; Cross, J.H. The ketogenic diet for the treatment of childhood epilepsy: A randomised controlled trial. Lancet Neurol. 2008, 7, 500-506. [CrossRef]

19. Falk, R.; Cederbaum, S.; Blass, J.; Gibson, G.; Kark, R.; Carrel, R. Ketonic diet in the management of pyruvate dehydrogenase deficiency. Pediatrics 1976, 58, 713-721. [PubMed]

20. Reed, L.J. Multienzyme Complexes. Acc. Chem. Res. 1973, 4, 40-46.

21. Masino, S.A.; Rho, J.M. Mechanisms of ketogenic diet action. Epilepsia 2010, 51 (Suppl. 5), 85. [CrossRef]

22. Sofou, K.; Dahlin, M.; Hallböök, T.; Lindefeldt, M.; Viggedal, G.; Darin, N. Ketogenic diet in pyruvate dehydrogenase complex deficiency: Short- and long-term outcomes. J. Inherit. Metab. Dis. 2017, 40, 237-245. [CrossRef] 
23. Zupec-Kania, B.A.; Spellman, E. An overview of the ketogenic diet for pediatric epilepsy. Nutr. Clin. Pract. 2008, $23,589-596$. [CrossRef]

24. Zupec-Kania, B.A.; Aldaz, V.; Kostas, K.C. Enteral and Parenteral Applications of Ketogenic Diet Therapy: Experiences From Four Centers. Infant Child. Adolesc. Nutr. 2011, 3, 274-281. [CrossRef]

25. Liu, Y.M.; Wang, H.S. Medium-chain triglyceride ketogenic diet, an effective treatment for drug-resistant epilepsy and a comparison with other ketogenic diets. Biomed. J. 2013, 36, 9-15. [CrossRef] [PubMed]

26. Kossoff, E.H.; Dorward, J.L. The modified Atkins diet. Epilepsia 2008, 49 (Suppl. 8), 37-41. [CrossRef] [PubMed]

27. Pfeifer, H.H.; Thiele, E.A. Low-Glyecmic-Index Treatment: A liberalized ketogenic diet for treatment of intractable epilepsy. Neurology 2005, 65, 1-3. [CrossRef] [PubMed]

28. Rauchenzauner, M.; Klepper, J.; Leiendecker, B.; Luef, G.; Rostasy, K.; Ebenbichler, C. The Ketogenic Diet in Children with Glut1 Deficiency Syndrome and Epilepsy. J. Pediatrics 2008, 153, 716-718. [CrossRef]

29. Wexler, I.D.; Hemalatha, S.G.; McConnell, J.; Buist, N.; Dahl, H.-H.M.; Berry, S.A.; Cederbaum, S.D.; Patel, M.S.; Kerr, D.S. Outcome of pyruvate dehydrogenase deficiency treated with ketogenic diets: Studies in patients with identical mutations. Neurology 1997, 49, 1655-1661. [CrossRef]

30. Kim, J.A.; Yu, R.; Jo, W.; Ko, Y.H.; Lee, J.-S.; Kim, H.D.; Kang, H.-C. A modified Atkin's diet for an infant with pyruvate dehydrogenase complex deficiency confirmed by PDHA1 gene mutation. Neurol. Asia 2014, 19, 327-329.

31. Chida, R.; Shimura, M.; Nishimata, S.; Kashiwagi, Y.; Kawashima, H. Efficacy of ketogenic diet for pyruvate dehydrogenase complex deficiency. Pediatrics Int. 2018, 60, 1041-1042. [CrossRef]

32. Martin, K.; Jackson, C.F.; Levy, R.G.; Cooper, P.N. Ketogenic diet and other dietary treatments for epilepsy. Cochrane Database Syst. Rev. 2016, 2, CD001903. [CrossRef]

33. Robinson, B.H.; Taylor, J.; Kahler, S.G.; Kirkman, H.N. Lactic acidemia, neurologic deterioration and carbohydrate dependence in a girl with dihydrolipoyl dehydrogenase deficiency. Eur. J. Pediatr. 1981, 136, 35-39. [CrossRef] [PubMed]

34. Craigen, W.J. Leigh Disease with Deficiency of Lipoamide Dehydrogenase: Treatment Failure with Dichloroacetate. Pediatric Neurol. 1996, 14, 69-71. [CrossRef]

35. Hong, Y.S.; Kerr, D.S.; Liu, T.; Lusk, M.; Powell, B.R.; Patel, M.S. Deficiency of dihydrolipoamide dehydrogenase due to two mutant alleles (E340K and G101del). Analysis of a family and prenatal testing. Biochim. Biophys. Acta 1997, 1362, 160-168. [CrossRef]

36. Saudubray, J.-M.; Baumgartner, M.; Walter, J. Inborn Metabolic Diseases; Springer: Heidelberg, Germany, 2016.

37. Ambrus, A.; Adam-Vizi, V. Human dihydrolipoamide dehydrogenase (E3) deficiency: Novel insights into the structural basis and molecular pathomechanism. Neurochem. Int. 2018, 117, 5-14. [CrossRef] [PubMed]

38. Vaubel, R.A.; Rustin, P.; Isaya, G. Mutations in the dimer interface of dihydrolipoamide dehydrogenase promote site-specific oxidative damages in yeast and human cells. J. Biol. Chem. 2011, 286, 40232-40245. [CrossRef] [PubMed]

39. Ruiz Herrero, J.; Cañedo Villarroya, E.; García Peñas, J.J.; García Alcolea, B.; Gómez Fernández, B.; Puerta Macfarland, L.A.; Pedrón Giner, C. Safety and Effectiveness of the Prolonged Treatment of Children with a Ketogenic Diet. Nutrients 2020, 12, 306. [CrossRef]

40. Cai, Q.Y.; Zhou, Z.J.; Luo, R.; Gan, J.; Li, S.P.; Mu, D.; Wan, C.M. Safety and tolerability of the ketogenic diet used for the treatment of refractory childhood epilepsy: A systematic review of published prospective studies. World J. Pediatr. 2017, 13, 528-536. [CrossRef] [PubMed]

41. Patel, A.; Pyzik, P.L.; Turner, Z.; Rubenstein, J.E.; Kossoff, E.H. Long-term outcomes of children treated with the ketogenic diet in the past. Epilepsia 2010, 51, 1277-1282. [CrossRef]

42. Martin-McGill, K.J.; Jackson, C.F.; Bresnahan, R.; Levy, R.G.; Cooper, P.N. Ketogenic diets for drug-resistant epilepsy. Cochrane Database Syst. Rev. 2020, 6, CD001903. [CrossRef]

43. Kossoff, E.H.; Dorward, J.L.; Turner, Z.; Pyzik, P.L. Prospective study of the modified Atkins diet in combination with a ketogenic liquid supplement during the initial month. J. Child Neurol. 2011, 26, 147-151. [CrossRef]

44. Sondhi, V.; Agarwala, A.; Chakrabarty, B.; Jauhari, P.; Lodha, R.; Pandey, R.M.; Toteja, G.S.; Paul, V.K.; Gulati, S. Dietary Therapy in Epilepsy Treatment (DIET-Trial): A Randomised Non-Inferiority Trial Comparing KD, MAD \& LGIT for Drug Resistant Epilepsy (S35.006). Neurology 2018, 90, S35.006.

45. Sakaguchi, Y.; Yoshino, M.; Aramaki, S.; Yoshida, I.; Yamashita, F.; Kuhara, T.; Matsumoto, I.; Hayashi, T. Dihydrolipoyl dehydrogenase deficiency: A therapeutic trial with branched-chain amino acid restriction. Eur. J. Nucl. Med. Mol. Imaging 1986, 145, 271-274. [CrossRef]

46. Bonnefont, J.-P.; Chretien, D.; Rustin, P.; Robinson, B.; Vassault, A.; Aupetit, J.; Charpentier, C.; Rabier, D.; Saudubray, J.-M.; Munnich, A. Alpha-ketoglutarate dehydrogenase deficiency presenting as congenital lactic acidosis. J. Pediatr. 1992, 121, $255-258$. [CrossRef]

47. Grafakou, O.; Oexle, K.; van den Heuvel, L.; Smeets, R.; Trijbels, F.; Goebel, H.H.; Bosshard, N.; Superti-Furga, A.; Steinmann, B.; Smeitink, J. Leigh syndrome due to a compound heterozygousity of dihydrolipoamide dehydrogenase gene mutations: Description of the first E3 splice site mutation. Eur. J. Pediatr. 2003, 162, 714-718. [CrossRef] 
48. Brassier, A.; Ottolenghi, C.; Boutron, A.; Bertrand, A.M.; Valmary-Degano, S.; Cervoni, J.P.; Chrétien, D.; Arnoux, J.B.; Hubert, L.; Rabier, D.; et al. Dihydrolipoamide dehydrogenase deficiency: A still overlooked cause of recurrent acute liver faliure and Reye-like syndrome. Mol. Genet. Metab. 2013, 109, 28-32. [CrossRef] [PubMed]

49. Elpeleg, O.N.; Christensen, E.; Hurvitz, H.; Branski, D. Recurrent, familial Reye-like syndrome with a new complex amino and organic aciduria. Eur. J. Nucl. Med. Mol. Imaging 1990, 149, 709-712. [CrossRef] 